\title{
CoNf-980905-
}

\section{PROCESS WASTEWATER TREATMENT WITH HYDROGEN-FORM \\ CST AND CHABAZITE ZEOLITE}

Susan M. DePaoli and Debra T. Bostick Lockheed Martin Energy Research Oak Ridge National Laboratory*

\section{SPECTRUM ' 98 CONFERENCE \\ DENVER, COLORADO \\ SEPTEMBER, 1998}

DISTRBSTION OF THS DOCUMENT IS UNLMMTED 


\section{DISCLAIMER}

This report was prepared as an account of work sponsored by an agency of the United States Government. Neither the United States Government nor any agency thereof, nor any of their employees, makes any warranty, express or implied, or assumes any legal liability or responsibility for the accuracy, completeness, or usefulness of any information, apparatus, product, or process disclosed, or represents that its use would not infringe privately owned rights. Reference herein to any specific commercial product, process, or service by trade name, trademark, manufacturer, or otherwise does not necessarily constitute or imply its endorsement, recommendation, or favoring by the United States Government or any agency thereof. The views and opinions of authors expressed herein do not necessarily state or reflect those of the United States Government or any agency thereof. 


\section{PROCESS WASTEWATER TREATMENT WTTH HYDROGEN-FORM CST AND CHABAZITE ZEOLITE}

\author{
S. M. DePaoli \\ Oak Ridge National Laboratory \\ P.O. Box 2008 \\ Oak Ridge, Tennessee 37831-6044 \\ (423) 574-6643
}

\author{
D. T. Bostick \\ Oak Ridge National Laboratory \\ P.O. Box 2008 \\ Oak Ridge, Tennessee 37831-6201 \\ (423) 576-7695
}

\begin{abstract}
Ion-exchange materials have been investigated for the removal of radionuclides from near-neutral-pH wastewaters containing competing cations at concentrations greater than those of the targeted species. Natural chabazite zeolite was chosen as the baseline material for the removal of fission products, namely ${ }^{90} \mathrm{Sr}$ and ${ }^{137} \mathrm{Cs}$, from wastewater and groundwater. The sorbent IONSIV ${ }^{\circ}$ IE-911, a c.ystalline silicotitanate manufactured by UOP, was recently tested in this capacity and found to compare extremely well against the baseline material in removing ${ }^{90} \mathrm{Sr}$ and ${ }^{137} \mathrm{Cs}$ from process wastewater. This paper presents results of similar column tests performed using both materials, as well as results from batch experiments on actual wastewaters using IONSIV ${ }^{\star}$ E-911.
\end{abstract}

\section{INTRODUCTION}

The Department of Energy (DOE) has supported the development of a number of new sorbents specific for the removal of ${ }^{90} \mathrm{Sr}$ and $/$ or ${ }^{137} \mathrm{Cs}$ from highly caustic tank supernatant waste. Among these is the inorganic exchanger crystalline silicotitanate (CST). ${ }^{1}$ The sorbent is selective for both ${ }^{90} \mathrm{Sr}$ and $/$ or ${ }^{137} \mathrm{Cs}$ and is now available in an engineered form (IONSIV ${ }^{\circ}$ IE-911) through UOP Molecular Sieves. Pelletized CST has been shown to perform well in removing strontium and cesium from dilute, near-neutral-pH wastewater as well, and is therefore applicable to the cleanup of secondary wastewater generated during decontamination activities, contaminated groundwater, and general process water produced at DOE facilities. ${ }^{2}$

An effort is now under way to evaluate IONSIV IE-911 for the treatment of radioactively contaminated wastewater generated at a number of DOE sites. Nearneutral-pH wastewaters present a more difficult challenge for radionuclide removal than tank waste for this sorbent due to the levels of soluble alkaline and alkaline-earth cations. Because concentrated DOE tank waste contains a significantly higher sodium ion concentration, the high-salt content and alkalinity $(\mathrm{pH}>12)$ negate the need for sorbent selectivity over calcium and magnesium ions, which are only minimally soluble in this waste matrix. Near-neutral-pH wastewaters, derived from contaminated groundwater or generated during reclamation and/or decontamination activities, contain soluble sodium, magnesium, potassium, and calcium ions that are usually 2-3 orders of magnitude greater in concentration than the total strontium content. Because cesium is present only as ${ }^{137} \mathrm{Cs}$ in these wastewaters, the relative concentration of competing cations is often eight orders of magnitude greater than that of cesium.

Several actual wastewaters have been tested; batch tests have been run to evaluate the efficiency of CST in removing the strontium and cesium from several of these waste matrices. Long-term column tests on a wastewater simulant representative of the process wastewater generated at Oak Ridge National Laboratory (ORNL) have been completed for both sorbents. Results from these experimental tests will be presented. The impact of waste $\mathrm{pH}$ and cation selectivity on the removal of radioactive strontium and cesium will be investigated.

The relative performance of the baseline sorbent, chabazite zeolite, will also be discussed. Zeolites have long been accepted as the ion-exchange material of choice for removing strontium and cesium from wastewater containing other competing cations. Both sorbents' physical characteristics, pretreatment procedures, relative ion-exchange capacities, sorption 
loading capacities, and nuclide distribution coefficients will be presented. Handling and operational characteristics of each sorbent under dynamic flow conditions will also be summarized.

\section{EXPERIMENTAL}

This work involves solutions containing very low concentrations of cationic species. Spectrophotometric (ICP and AA) and radiotracer methodologies were used to determine the identity and concentrations of the chemical species in batch and column tests.

Much of the information concerning a sorbent is obtained through the experimental isotherm. Isotherms of strontium and cesium sorption on CST have been developed at room temperature using two methods: one in which the amount of sorbent is kept constant and the species concentration in solution is varied and the second, in which the sorbent is introduced in varying amounts to a constant concentration solution. These isotherms can then be interpreted to provide information on loading capacities, decontamination factors, and equilibrium constants.

Batch information was gathered by contacting known amounts of sorbent and simulant or wastewater in polycarbonate centrifuge tubes on a Labquake ${ }^{\mathrm{TM}}$ shaker. At the conclusion of the equilibration period, the solutions were clarified through $0.45-\mu \mathrm{m}$ filters and then analyzed.

All column tests were run using a $1-\mathrm{cm}$-diameter column containing approximately $4 \mathrm{~g}$ of sorbent. Bed volumes were about $4 \mathrm{~mL}$, and nominal simulant flow rates of approximately $1.2 \mathrm{~mL} / \mathrm{min}$ were established in the columns, corresponding to 19 bed volumes (BV) per hour. Residence times were approximately 3 minutes.

\section{RESULTS}

The physical and chemical characteristics of chabazite zeolite and CST have been gathered from various literature sources or determined experimentally where data were not available. Table 1 summarizes these characteristics.

\section{A. Chemical Characterization and Pretreatment}

CST sorbent can exist in multiple ionic forms. ${ }^{3}$ The form of CST undergoing exchange with strontium and cesium is a function of both the sodium ion concentration and the $\mathrm{pH}$ in the waste. In a recent publication, Zheng et al. ${ }^{3}$ defined CST functionality
Table 1. Comparative sorbent characteristics.

\begin{tabular}{|c|c|}
\hline Chabazite zeolite & $\begin{array}{l}\text { Crystalline silicotitanate: } \\
\text { IONSIV IE-911 }\end{array}$ \\
\hline Source: GSA Resources, Inc. & Source: UOP. Molecular Sieves \\
\hline $\begin{array}{l}\text { Naturally occurring, inorganic } \\
\text { zeolite }\end{array}$ & $\begin{array}{l}\text { Inorganic, engineered pellets; } \\
\text { framework of aluminosilicate }\end{array}$ \\
\hline Exchangeable cation: sodium & $\begin{array}{l}\text { Exchangeable cations: } \\
\text { sodium and hydrogen }\end{array}$ \\
\hline Sorbent cost: $\$ 50 / \mathrm{ft}^{3}$ & Sorbent cost: $\$ 7200 / \mathrm{ft}^{3}$ \\
\hline Bulk density: $1.73 \mathrm{~g} / \mathrm{cm}^{3}$ & $\begin{array}{l}\text { Bulk density: } 1.0 \mathrm{~g} / \mathrm{cm}^{3} ; \\
\text { Particle density: } 2.00 \mathrm{~g} / \mathrm{cm}^{3}\end{array}$ \\
\hline Avg. particle size: $480 \pm 220 \mu \mathrm{m}$ & Avg particle size: $410 \pm 110 \mu \mathrm{m}$ \\
\hline $\begin{array}{l}\text { Order of selectivity } \\
\text { in process waste simulant: } \\
\qquad \mathrm{Na}<\mathrm{Mg}<\mathrm{Ca}<\mathrm{Sr}<\mathrm{Cs}\end{array}$ & $\begin{array}{l}\text { Order of selectivity } \\
\text { in process waste simulant: } \\
\qquad \mathrm{Mg}<\mathrm{Ca}_{\mathrm{a}}<\mathrm{Na}<\mathrm{K}<\mathrm{Sr}<\mathrm{Cs}\end{array}$ \\
\hline $\begin{array}{l}\text { Operating characteristics: } \\
\text { Material is friable; tends to break } \\
\text { down prior to complete loading, } \\
\text { causing column plugging }\end{array}$ & $\begin{array}{l}\text { Operating characteristics: } \\
\text { Material appears to be } \\
\text { structurally stable; in column test } \\
\text { over } 10 \text { months, no noticeable } \\
\text { plugging or fines produced }\end{array}$ \\
\hline Pretreatment needs: $\mathrm{NaCl}$ wash & $\begin{array}{l}\text { Pretreatment needs: } \mathrm{HCl} \text { wash for } \\
\text { treatment of near-neutral-pH } \\
\text { waste }\end{array}$ \\
\hline $\begin{array}{l}\text { Ion-exchange capacity: } \\
2.2 \mathrm{meq} / \mathrm{g}\end{array}$ & $\begin{array}{l}\text { Ion-exchange capacity: } \\
1.36 \mathrm{meq} / \mathrm{g}\end{array}$ \\
\hline
\end{tabular}

in sodium solutions according to the following equilibrium reactions:

$$
\begin{gathered}
\mathrm{H}^{+}+\mathrm{Na}_{3}-\mathrm{CST} * \mathrm{HNa}_{2}-\mathrm{CST}+\mathrm{Na}^{+} \quad k_{1}=7.7 \times 10^{8}, \\
\mathrm{H}^{+}+\mathrm{HNa}_{2}-\mathrm{CST} * \mathrm{H}_{2} \mathrm{Na}-\mathrm{CST}+\mathrm{Na}^{+} \quad k_{2}=6.1 \times 10^{7},
\end{gathered}
$$

and

$$
\mathrm{H}^{*}+\mathrm{H}_{2} \mathrm{Na}-\mathrm{CST}=\mathrm{H}_{3}-\mathrm{CST}+\mathrm{Na}^{+} \quad k_{3}=7.4
$$

The concentration of each CST form can be rewritten in terms of the preceding equilibrium constants; for example,

$$
\left[\mathrm{HNa}_{2}-\mathrm{CST}\right]=k_{1} \frac{\left[\mathrm{Na}_{3}-\mathrm{CST}\right]\left[\mathrm{H}^{+}\right]}{\left[\mathrm{Na}^{+}\right]}
$$


An overall mass balance can be written

$$
[\mathrm{CST}]=\left[\mathrm{Na}_{3}-\mathrm{CST}\right]+\left[\mathrm{HN} 2_{2}-\mathrm{CST}\right]+\left[\mathrm{H}_{2} \mathrm{Na}-\mathrm{CST}\right]+\left[\mathrm{H}_{3}-\mathrm{CST}\right] .
$$

The distribution of CST functionality in a given waste matrix can then be determined as a function of the equilibrium constants. For example, the fractional contribution of the trisodium form of CST to the overall $\mathrm{IONSIV}^{\circ}$ IE-9I1 functionality can be determined as

$$
\frac{\left[\mathrm{Na}_{3}-\mathrm{CST}\right]}{[\mathrm{CST}]}=\frac{1}{k_{1} \frac{\left[\mathrm{H}^{+}\right]}{\left[\mathrm{Na}^{+}\right]}+k_{1} k_{2} \frac{\left[\mathrm{H}^{+}\right]^{2}}{\left[\mathrm{Na}^{+}\right]^{2}}+k_{1} k_{2} k_{3} \frac{\left[\mathrm{H}^{+}\right]^{3}}{\left[\mathrm{Na}^{+}\right]^{3}}}
$$

Each of the other CST forms can be similarly represented. For typical nuclear tank waste containing $5 \mathrm{M}$ sodium ion and a $\mathrm{pH}$ greater than 11 , equilibrium calculations indicate that the trisodium CST will be the primary form of CST undergoing exchange. However, the monosodium form of CST is the primary form of the exchanger in near-neutral wastewater streams (Fig. 1). Even if the total sodium content is as great as $5 \mathrm{M}$, over $98 \%$ of CST will hydrolyze to the monosodium form in a near-neutral, equilibrated solution.

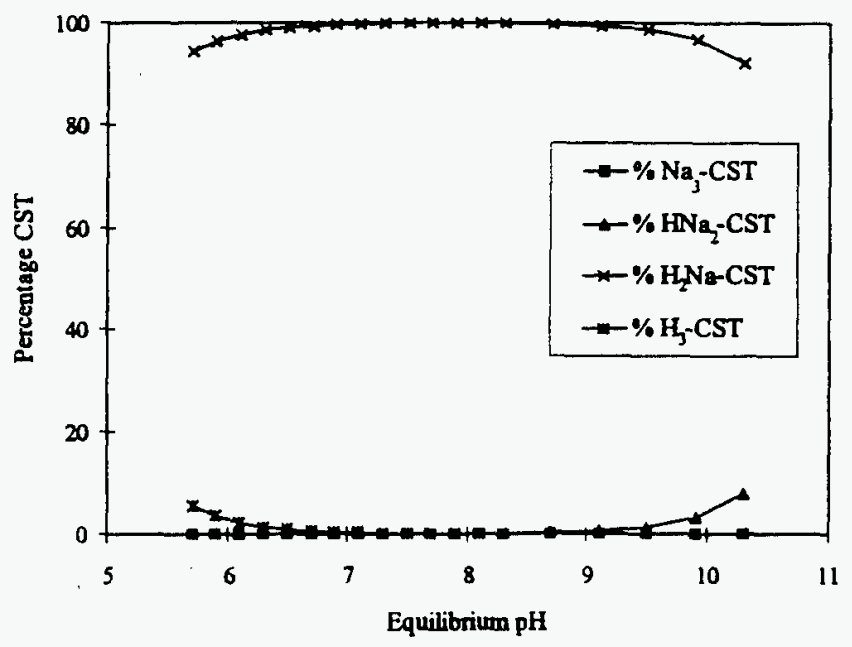

Figure 1. CST functionality in $\mathbf{1 5} \mathrm{ppm}$ sodium solution.

The implication of the preceding calculations is that efforts to convert CST to either the trisodium or the trihydrogen form are not particularly effective for wastewater applications. According to directions supplied by UOP, IONSIV ${ }^{\star}$ IE-911 should be converted to the trisodium form by pretreating the CST with $\mathrm{NaOH}$. Complete conversion to the trisodium CST ensures that the exchanger will have the greatest exchange capacity in highly alkaline tank matrices and that the $\mathrm{pH}$ of the waste is not altered by any exchange of hydrogen on the CST with sodium ions present in the waste solution. However, in near-neutral waste matrices, the formation of the monosodium CST is highly favored, such that trisodium CST immediately hydrolyzes and elevates the pH of the process wastewater. The secondary consequence of CST hydrolysis is the possibility that near-saturation levels of calcium present in groundwater might precipitate as the $\mathrm{pH}$ of the waste increases.

Conversely, if the CST is pretreated with $\mathrm{HCl}$ to form trihydrogen CST, monosodium CST is rapidly formed by the uptake of sodium from process wastewater and the release of hydrogen ions into the waste stream.

Zeolite performance was enhanced when the natural strontium in the matrix was replaced with sodium using a $2.0 \mathrm{M} \mathrm{NaCl}$ wash. This pretreatment, along with sieving and a water wash, also served to reduce fines as well.

\section{B. Column Tests}

Small-column tests have been performed using both sorbent materials on a simulated process wastewater typical of DOE wastewater streams (Table 2). Total strontium is present at a concentration of about $0.1 \mathrm{ppm}$, and peak concentrations of cesium run about $3.4 \times 10^{-4} \mathrm{ppm}$ in this wastewater. Average cesium concentrations of $9.4 \times 10^{-8} \mathrm{ppm}$ are normally present in the wastewater, thus, the simulant tests were run at cesium concentrations approximately $5 \times 10^{4}$ times higher than average.

Table 2. Process wastewater compositions.

\begin{tabular}{lcc}
\hline \multirow{2}{*}{ Component } & \multicolumn{2}{c}{ Concentration (mg/L) } \\
\cline { 2 - 3 } & PWTP, actual & PWTP, simulant \\
\hline $\mathrm{Ca}^{2+}$ & $35-40$ & 45 \\
$\mathrm{Cs}^{+}$ & $9.4 \times 10^{-4}$ & $3.4 \times 10^{-4}$ \\
& $(300 \mathrm{~Bq} / \mathrm{L})$ & $\left(1.1 \times 10^{6} \mathrm{~Bq} / \mathrm{L}\right)$ \\
$\mathrm{K}^{+}$ & $1-3$ & 1.2 \\
$\mathrm{Mg}^{2+}$ & $7-8$ & 8.8 \\
$\mathrm{Na}^{+}$ & $14-30$ & 18.3 \\
$\mathrm{Sr}^{2+}$ (total) & 0.1 & 0.1 \\
$\mathrm{Sr}^{2+}$ (radioactive) & $5.3 \times 10^{-3} \mathrm{as}{ }^{90} \mathrm{Sr}$ & $0.0002 \mathrm{as}$ \\
& $(270 \mathrm{~Bq} / \mathrm{L})$ & $\left(1 \times 10^{6} \mathrm{~Bq} / \mathrm{L}\right)$ \\
$\mathrm{pH}$ & $6.7-9$ & $7-8$ \\
\hline
\end{tabular}


Figures 2 and 3 show the cationic and radioactive species breakthrough curves, respectively, on the chabazite zeolite. The zeolite selectively removed strontium and cesium. The $50 \%$ breakthrough for strontium and cesium occurred at 13,000 and $50,000 \mathrm{BV}$, respectively, while $50 \%$ breakthrough of major cations ( $\mathrm{Ca}, \mathrm{Mg}$, and $\mathrm{Na}$ ) was seen between 100 and $600 \mathrm{BV}$; therefore, a separation of approximately $12,500 \mathrm{BV}$ (at $50 \%$ breakthrough) was seen between cationic and strontium breakthroughs. Distribution coefficients $\left(K_{d}\right)$ and loading capacities $\left(L_{c}\right)$ are given in Table 3.

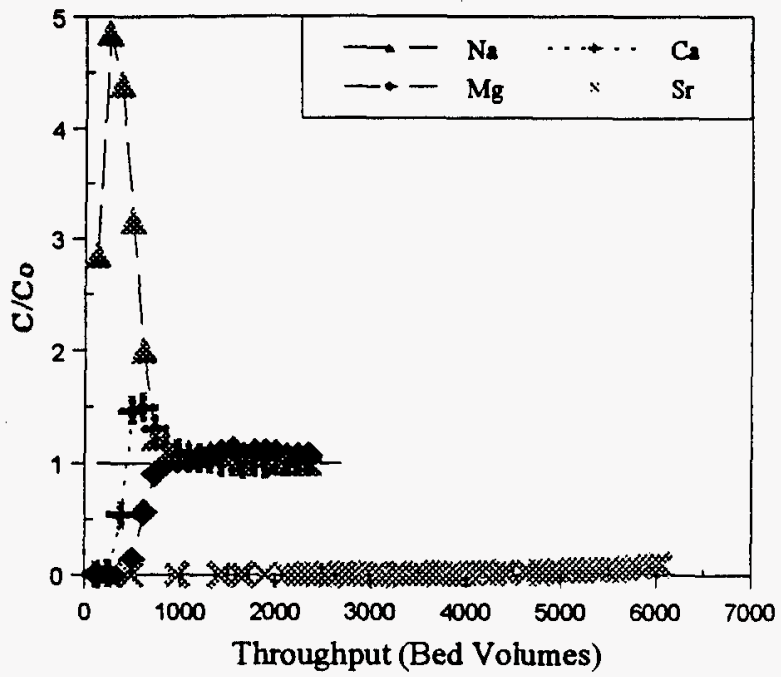

Figure 2. Breakthrough of competing cations on zeolite.

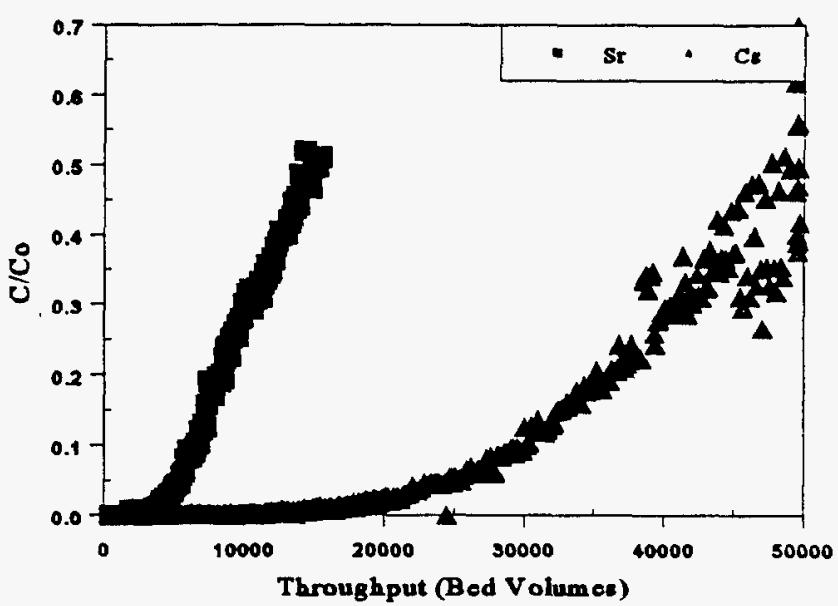

Figure 3. Breakthrough of strontium and cesium on zeolite.
Table 3. Loading capacities $\left(L_{c}\right)$ and distribution coefficients $\left(K_{\mathcal{l}}\right)$ for strontium and cesium removal from PWTP simulant.

\begin{tabular}{ccccc}
\hline & \multicolumn{2}{c}{$\begin{array}{c}\text { Strontium } \\
(0.0023 \mathrm{meq} / \mathrm{L})\end{array}$} & $\begin{array}{c}\text { Cesium } \\
\left(3.2 \times 10^{-6} \mathrm{meq} / \mathrm{L}\right)\end{array}$ \\
\cline { 2 - 5 } & $\begin{array}{c}\mathrm{L}_{\mathrm{e}} \\
(\mathrm{meq} / \mathrm{kg})\end{array}$ & $\begin{array}{c}\mathrm{K}_{\mathrm{d}} \\
(\mathrm{Lkg})\end{array}$ & $\begin{array}{c}\mathrm{L}_{\mathrm{e}} \\
(\mathrm{meq} / \mathrm{kg})\end{array}$ & $\begin{array}{c}\mathbf{K}_{\mathrm{d}} \\
(\mathrm{LKg})\end{array}$ \\
\hline $\begin{array}{c}\text { IONSIV- } \\
\text { IE-911 }\end{array}$ & 1050 & $6 \times 10^{5}$ & 26 & $8 \times 10^{6}$ \\
$\begin{array}{c}\text { Chabazite } \\
\text { zeolite }\end{array}$ & 24 & $1.7 \times 10^{4}$ & 0.2 & $8 \times 10^{4}$ \\
\hline
\end{tabular}

The CST also selectively removed strontium and cesium, with $50 \%$ breakthroughs of major cations (Ca, $\mathrm{Mg}$, and $\mathrm{Na}$ ) occurring at less than $1300 \mathrm{BV}$ and potassium at 15,000 BV. Figures 4 and 5 show the breakthrough curves of the competing cations and radioactive species. The column experiment was terminated at $120,000 \mathrm{BV}$, at which time strontium breakthrough was at $15 \%$. Assuming a linear breakthrough for strontium, $50 \%$ removal would have occurred at approximately $178,500 \mathrm{BV}$. Breakthrough of cesium had not been observed throughout the test. Thus a separation of approximately $177,000 \mathrm{BV}$ between cationic and strontium breakthroughs (with the exception of potassium, where the separation was $163,000 \mathrm{BV}$ ) was demonstrated for the CST, as opposed to the $12,500 \mathrm{BV}$ for the zeolite. Table 3 summarizes the $K_{d}$ and $L_{c}$ values for the radionuclides in PWTP simulant. Cesium values were calculated based on a predictive sorption model developed by Gu et. al. ${ }^{4}$

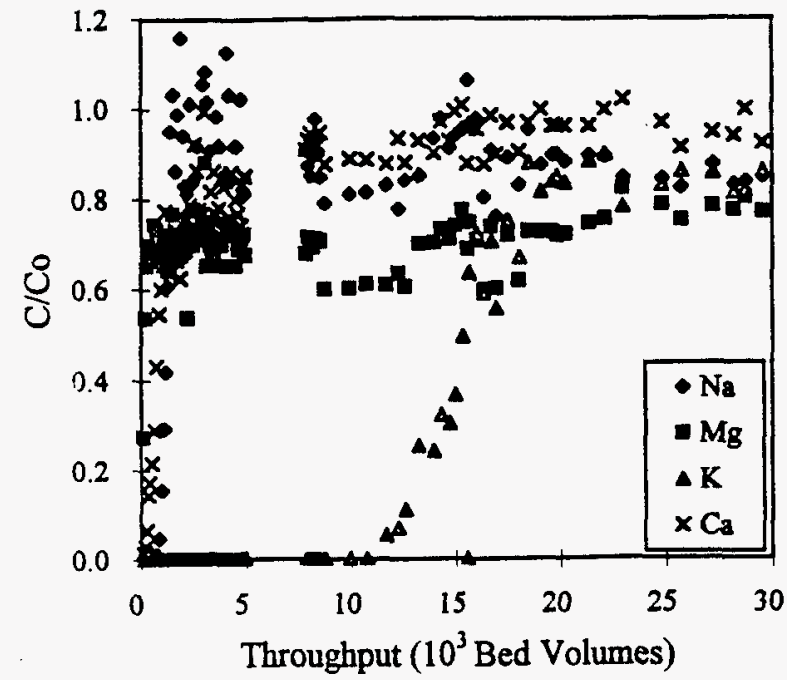

Figure 4. Breakthrough of competing cations on hydrogen-form CST. 
Figure 5 also includes the changing $\mathrm{pH}$ as a function of feed through the column (in BV). CST contains both sodium and hydrogen exchange sites. The initial low $\mathrm{pH}$ of the column effluent demonstrates the release of hydrogen ions as the other cations are loaded. Dips in $\mathrm{pH}$ throughout the column test corresponded with increasing loading of strontium, supporting the earlier discussion of multiple exchange sites on the CST.

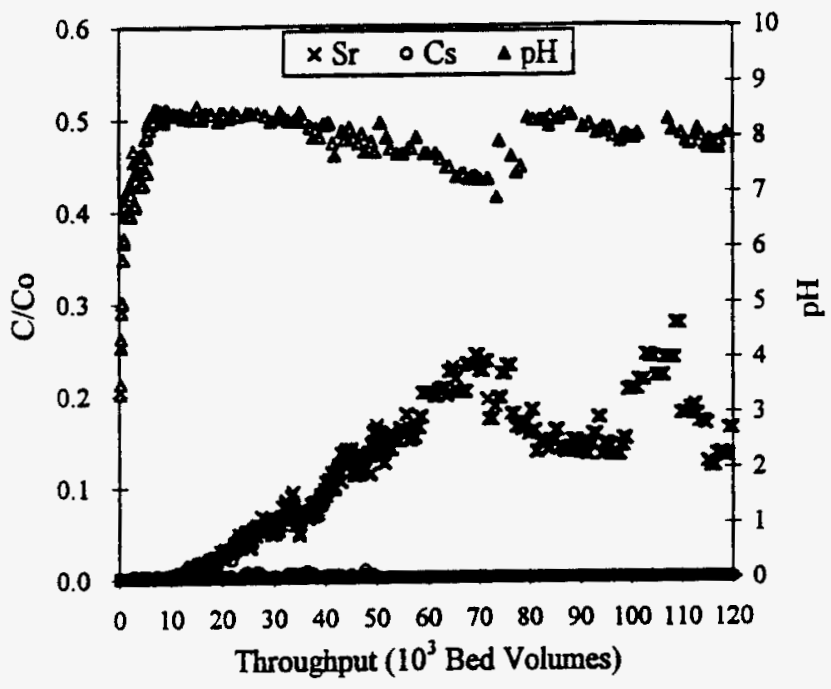

Figure 5. Breakthrough of strontium and cesium on hydrogen-form CST.

\section{Batch Tests on Actual Wastewaters}

Batch tests were performed on actual wastewaters to further define the capabilities of CST for removing strontium and cesium in the presence of competing cations. The cationic compositions of the two additional wastestreams that were treated are shown in Table 4.

The Central Neutralization Facility (CNF), located at the former K-25 Site, Oak Ridge, provides treatment for radiologically contaminated effluent derived from the Toxic Substance Control Act (TSCA) mixed-waste incinerator. The bulk of the dissolved solids in the aqueous stream consists of the chloride and sulfate salts of calcium and sodium (see Table 4).

Currently, the primary radiological contaminant is uranium, which is removed by iron coprecipitation. However, if ORNL wastes are incinerated at TSCA, both presence of ${ }^{90} \mathrm{Sr}$ and ${ }^{137} \mathrm{Cs}$ in the TSCA blowdown liquor will require an additional decontamination operation at CNF specific for these nuclides. Because of the high salt
Table 4. Composition of major cations and radionuclides in wastewater streams.

\begin{tabular}{|c|c|c|}
\hline \multirow[b]{2}{*}{ Element } & \multicolumn{2}{|c|}{ Concentration (ppm) } \\
\hline & K-25 TSCA blowdown" & $\begin{array}{c}\text { Gunite Tank (GAAT) } \\
\text { wastewater }\end{array}$ \\
\hline $\mathrm{Ca}_{2}$ & $\begin{array}{c}3-400 \\
\text { (average }=65 \text { ) }\end{array}$ & 20 \\
\hline $\mathbf{K}$ & 6 & 18 \\
\hline $\mathbf{M g}$ & $\begin{array}{c}1-150 \\
\text { (average }=20 \text { ) }\end{array}$ & 11 \\
\hline $\mathrm{Na}$ & $\begin{array}{c}8-7000 \\
(\text { average }=400)\end{array}$ & 400 \\
\hline $\begin{array}{l}\mathrm{Sr} \text { (total) } \\
{ }^{*} \mathrm{Sr}\end{array}$ & 0.3 & $\begin{array}{c}0.1 \\
77 \times 10^{4} \mathrm{~B} q \mathrm{~L}\end{array}$ \\
\hline${ }^{137} \mathrm{Cs}$ & $\mathrm{TBD}^{\mathrm{b}}$ & $98 \times 10^{5} \mathrm{BqL}$ \\
\hline
\end{tabular}

A. C. Coroneos et. al., Bench Scale Treatability Studies for Simulated Incinerator Scrubber Blowdown Containing Radioactive Cesium and Strontium, ORNL/TM-12823 (Dec. 1994).

TBD = To be determined upon incineration of ${ }^{\text {s. }} \mathrm{Sr}$ - and ${ }^{137} \mathrm{C}$ - bearing waste at TSCA.

content of CNF wastewater, neither chabazite nor clinoptilolite zeolite are suitable for the removal of ${ }^{90} \mathrm{Sr}$ and ${ }^{137} \mathrm{Cs}$ directly from the stream. ${ }^{5}$ In previous testing of zeolite for the removal of these radioactive constituents from a simulated waste, complete breakthrough on zeolite for all competing cations and strontium was observed in the first $25 \mathrm{BV}$ of column operation; cesium breakthrough occurred at greater than $500 \mathrm{BV}^{\mathrm{s}}$

CST was initially developed for removal of strontium and cesium from high $(5 \mathrm{M}) \mathrm{NaCl}$ matrices. Therefore, the presence of high concentrations up to $7000 \mathrm{ppm} \mathrm{Na}(0.3 \mathrm{M})$ in CNF waste is not expected to significantly suppress radionuclide sorption, as in the case of zeolite treatment. It is the calcium and potassium content in the waste that will primarily affect the removal efficiency of strontium by CST.

An actual sample of $\mathrm{CNF}$ wastewater was spiked with strontium and cesium to the levels shown in Table 5. Batch testing results for removal of strontium and cesium from this wastewater using the

IONSIV $^{*}$ IE-911 are summarized in Table 5. The $\mathrm{K}_{d}$ for strontium, and thus the strontium loading capacity, $\mathrm{L}_{c}$, are reduced by greater than a factor of 10 in CNF waste as compared to PWTP waste. Because CST has a relatively greater selectivity for cesium over potassium and calcium, the cesium $K_{d}$ is not as severely depressed in $\mathrm{CNF}$ waste. Batch sorption results indicate that a 
Table 5. Loading capacities $\left(L_{\mathbf{b}}\right)$ and distribution coefficients $(K$,$) for strontium and cesium removal$ from various wastewaters using IONSIV IE-911.

\begin{tabular}{|c|c|c|c|c|}
\hline \multirow{2}{*}{$\begin{array}{l}\text { Wastewater } \\
\text { source }\end{array}$} & \multicolumn{2}{|c|}{$\begin{array}{c}\text { Strontium } \\
(0.0023 \mathrm{meq} / \mathrm{L})\end{array}$} & \multicolumn{2}{|c|}{$\begin{array}{l}\text { Cesium } \\
\left(3.2 \times 10^{-6} \mathrm{meq} / \mathrm{L}\right)\end{array}$} \\
\hline & $\begin{array}{c}\mathrm{L}_{\mathrm{c}} \\
(m e q / \mathrm{kg})\end{array}$ & $\begin{array}{c}K_{\mathbf{y}} \\
(\mathbf{L} \mathbf{k g})\end{array}$ & $\underset{(m e q / k g)}{L_{k}}$ & $\underset{(\mathbf{L} / \mathbf{k g})}{\mathbf{K}_{\mathbf{g}}}$ \\
\hline $\begin{array}{c}\text { PWTP } \\
\text { simulant }\end{array}$ & 1050 & $6 \times 10^{5}$ & 26 & $8 \times 10^{6}$ \\
\hline CNF & 79 & $3 \times 10^{4}$ & 6.3 & $3 \times 10^{6}$ \\
\hline GAAT & 0.25 & $2 \times 10^{2}$ & 0.8 & $3.6 \times 10^{5}$ \\
\hline $\begin{array}{l}\text { GAAT } \\
\text { simulant }\end{array}$ & 3.2 & $1.5 \times 10^{3}$ & 5 & $1.3 \times 10^{6}$ \\
\hline
\end{tabular}

CST loading of $0.5 \mathrm{mg} / \mathrm{g} \mathrm{CNF}$ waste would result in decontamination factors of 10 and 1000 for strontium and cesium, respectively. This level of decontamination, particularly in the case of strontium, will meet the minimum needs of CNF operations.

A third source of wastewater representing secondary waste derived from water scarification of inactive Gunite and associated waste tanks (GAAT) at the ORNL site, has recently been analyzed for cation content. iote that the potassium concentration of the waste given in Table 4 is significantly greater than in the other two wastewater sources. If the ${ }^{90} \mathrm{Sr}$ and ${ }^{137} \mathrm{Cs}$ in the GAAT wastewater could be reduced by a factor of 500-1000, it could be transferred directly to the Process Waste Treatment Plant (PWTP) for treatment and eventual discharge, thus saving on storage and further treatment of thousands of gallons of liquid low-level waste.

Batch uptake tests have been run to determine how effective IONSIV IE-911 will be in treating the nearneutral-pH, high-salt waste stream. Initial results indicated that the strontium was not removed from the waste (Table 5), but the decontamination factor for cesium was greater than 1200 .

A second set of batch tests were completed to determine whether the presence of trace complexing agents or the relatively high concentration of potassium ion (20 ppm) in the actual waste might have suppressed strontium removal. A GAAT waste simulant was prepared that reflected the composition of the scarification water but contained no organic constituents. A comparison of the $K_{d}$ for cesium in PWTP (1 ppm potassium) and GAAT (20 ppm potassium) simulants indicates that the elevated potassium concentration suppresses the $K_{d}$ by a factor of two. Similarly, the strontium $\mathrm{K}_{\mathrm{d}}$ is reduced by a factor of thirty. A comparison of sorption results between actual and simulant GAAT samples demonstrates that organic complexants further reduce the strontium and cesium $\mathrm{K}_{\mathrm{d}}$ values by a factor of ten and four, respectively. These batch tests conclusively demonstrate that $\mathrm{IONSIV}^{\circ} \mathrm{IE}$ 911 can be used to adequately remove cesium from GAAT wastewater. However, high concentrations of potassium and trace levels of organic complexants preclude the use of CST for strontium removal in this application.

\section{CONCLUSIONS}

A comparison of breakthrough data for CST and baseline zeolite processing PWTP wastewater simulant illustrate that both exchangers sorb calcium to approximately the same degree, with maximum sorption ratios of about $1200 \mathrm{~L} / \mathrm{kg}$ in both batch and column configurations. Magnesium is more strongly exchanged on zeolite compared with CST by almost a factor of three. Potassium appears to be strongly exchanged on the CST, with a column distribution coefficient of about $17,000 \mathrm{~L} / \mathrm{kg}$. Data for potassium exchanging on the zeolite are not available because the potassium concentration in the simulant was below the ICP detection limit at that time.

The $K_{d}$ 's measured during batch tests using CST for removal of Sr and Cs from process wastewater simulant show an enormous loading capacity for ${ }^{137} \mathrm{Cs}$, which is supported by the column work to date. The $\mathrm{K}_{d}\left({ }^{137} \mathrm{Cs}\right.$ on CST $=8,000,000 \mathrm{~L} / \mathrm{kg}$ as calculated by Gu et. al. ${ }^{4}$ ) is two orders of magnitude greater than that observed on zeolite. Strontium removal from ORNL wastewater in the CST column study is projected to achieve a maximum possible $\mathrm{K}_{\mathrm{d}}$ of about $600,000 \mathrm{~L} / \mathrm{kg}$ at $50 \%$ breakthrough. In comparison, the $\mathrm{K}_{\mathrm{d}}$ for strontium exchange on zeolite was $17,000 \mathrm{~L} / \mathrm{kg}$ at $50 \%$ breakthrough (see Table 5).

During the column tests, it was apparent that, physically, the CST is more robust than zeolite. No problems with plugging were noted with the CST, whereas the zeolite produced fines that cemented together and prevented column flow at 50,000 BV. The column results and calculated breakthrough points for wastewater cations imply the wastewater treatment using CST will be advantageous under variable stream compositions. The physical durability of the sorbent suggests that CST will not degrade over the extended lifetime of the high capacity columns. 
The effectiveness of wastewater treatment with zeolite is very dependent on the concentration of competing cations. Whereas variation in sodium concentration significantly affects radionuclide sorption on zeolite, sorption on CST is not similarly affected.

The primary factors limiting the use of CST for wastewater treatment appear to be the presence of organic complexors that bind with strontium and high levels of potassium that compete with both strontium and cesium in the ion-exchange process.

\section{REFERENCES}

1. R. G. Anthony, R. G. Dosch, D. Gu, and C. V. Philip, "Use of Silicotitanates for Removing Cesium and Strontium from Defense Waste," Ind. Eng. Chem. Res., 33, 2702-2705 (1994).

2. D. T. Bostick, S. M. DePaoli, and B. Guo, Evaluation of Improved Techniques for the Removal of Fission Products from Process Wastewater and Groundwater: FY 1997 Status, ORNL/TM-13497 (Feb. 1998).

3. Z. Zheng, R. G. Anthony, and J. E. Miller, "Modeling Multicomponent Ion Exchange Equilibrium Utilizing Hydrous Crystalline Silicotitanates by a Multiple Interactive Ion Exchange Model," Ind. Eng. Chem. Res., 36, 2427-2434 (1997).

4. D. Gu, L. Nguyen, C. V. Philip, M. E. Huckman, and $\mathrm{R}$ G. Anthony, " $\mathrm{Cs}^{+}$Ion Exchange Kinetics in Complex Electrolyte Solutions Using Hydrous Crystalline Silicotitanates," Ind. Eng. Chem. Res., 36, 5377-5383 (1997).

5. A. C. Coroneos et. al., Bench Scale Treatability Studies for Simulated Incinerator Scrubber Blowdown Containing Radioactive Cesium and Strontium, ORNL/TM-12823 (Dec. 1994). 


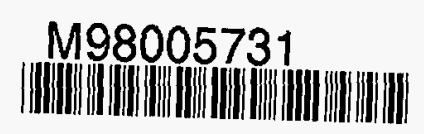

Report Number (14, ORNL/CP-- 98275

CONF-980905=-

Publ. Date (11) 199805.
Sponsor Code (18) DOE/EM, XF
UC Category (19) $4 C-2000$, DOE/ER

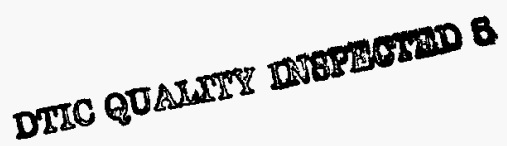

19980720025

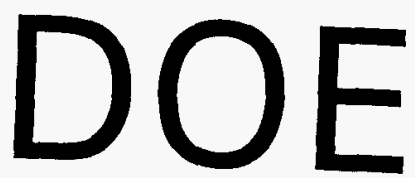

